\title{
Textile prostheses in abdominal and pelvic surgery DOI: 10.35530/IT.072.05.202020
}

\author{
ALEXANDRU-FLORIN SĂVULESCU \\ CRISTIAN CÎRLAN \\ ANCA A. SIMIONESCU \\ ANDREEA-IULIA BUDRUGEAC \\ MĂDĂLINA IORDACHE-PETRESCU
}

\author{
MIHAI IORDACHE \\ ALEXANDRA-BIANCA IONESCU \\ DRAGOŞ STANCIU \\ EMMA-ILINCA SBÂRNEA \\ OANA CORINA CĂLINA
}

\begin{abstract}
REZUMAT
Textile prostheses in abdominal and pelvic surgery

Textile prostheses have been used in abdominal surgery since ancient times. Industrial development of the last one hundred years changed it from simple cloth to highly improved materials that are better integrated and provide superior functional outcomes.

Understanding of the physicochemical properties of surgical meshes is essential for the rational choice of the optimal device. This needs to be closely adapted to mechanical and biological conditions of the anatomical region that will be placed in. The quality of the materials and the manufacturing technique are also of great importance, influencing both the mechanical parameters and the integration of the prosthetic material. Although a hard-to-reach concept, the ideal mesh should have high porosity, a monofilamentous structure and it should be composed of durable, non-carcinogenic, non-allergenic, and highly biocompatible materials. These qualities will ensure a good integration of the prosthesis and will make it easy to handle intraoperatively, resulting in a satisfactory clinical outcome.

Based on the above considerations, this article aims to bring to light useful manufacturing information regarding textile prostheses used in surgical reconstructions, in order to support surgeons in making the correct and rational choice of the prosthetic material, based on its physicochemical properties, thus avoiding postoperative complications.

Textile implants apply to various surgical fields such as abdominal or thoracic wall reconstruction, visceral defect repair, pelvic floor stabilization or tissue replacement.

Postoperative complications of mesh use include chronic pain, infection, ulceration of the wound, adhesion formation, intestinal obstruction, recurrence of parietal defect, rejection of the prosthesis, and mesh granuloma.
\end{abstract}

Keywords: surgical mesh, hernia, transobturatory tape procedure, mechanical properties, structural parameters

\section{Protezele textile în chirurgia abdominală și pelviană}

Protezele textile au fost utilizate în chirurgia abdominală încă din cele mai vechi timpuri. Dezvoltarea industrială din ultimii o sută de ani a schimbat proteza textilă de la o simplă pânză la materiale extrem îmbunătățite, care sunt mai bine integrate și oferă rezultate funcționale superioare.

Înțelegerea proprietăților fizico-chimice ale plaselor chirurgicale este esențială pentru alegerea rațională a dispozitivului optim. Acest lucru trebuie adaptat îndeaproape la condițiile mecanice și biologice ale regiunii anatomice în care va fi plasat. Calitatea materialelor și tehnica de fabricație sunt, de asemenea, de o mare importanță, influențând atât parametrii mecanici, cât și integrarea materialului protetic. Deși este un concept greu accesibil, plasa chirurgicală ideală ar trebui să aibă o porozitate ridicată, o structură monofilamentară și ar trebui să fie compusă din materiale durabile, non-cancerigene, non-alergenice și extrem de biocompatibile. Aceste calități vor asigura o bună integrare a protezei și vor facilita manipularea intraoperatorie, cu un rezultat clinic satisfăcător.

Pe baza considerațiilor de mai sus, acest articol își propune să aducă la lumină informații utile de fabricație privind protezele textile utilizate în reconstrucțiile chirurgicale, pentru a sprijini chirurgii în alegerea corectă și rațională a materialului protetic, pe baza proprietăților sale fizico-chimice, evitând astfel complicațiile postoperatorii.

Implanturile textile se aplică în diverse domenii chirurgicale, cum ar fi reconstrucția peretelui abdominal sau toracic, repararea defectelor viscerale, stabilizarea planșeului pelvin sau înlocuirea țesuturilor.

Complicațiile postoperatorii ale utilizării plaselor includ durerea cronică, infecția, ulcerația plăgii, formarea aderențelor, obstrucția intestinală, recurența defectului parietal, respingerea plasei și granulomul de fir.

Cuvinte-cheie: plasă chirurgicală, hernie, procedeul benzii transobturatoare, proprietăți mecanice, parametri structurali

\section{INTRODUCTION}

Reconstructive surgery for inguinal hernias is one of the most frequent surgeries involving textile prosthesis (meshes). Hernia has been first mentioned in history in the $16^{\text {th }}$ century $\mathrm{BC}$, when recognized by
Praxagoras of Kos as surgical pathology which needed immediate treatment [1]. As Hippocrates reveals, traces of textile materials sutured with golden threads were found in Egyptian sarcophaguses.

Subsequently, there were used silver filigrees, representing the first mesh created by the ancient Greeks 
[2]. The term "prosthesis" actually comes from the ancient Greek prostíthēmi, as prós means "near" or "attachedv and títhēmi means "to place" [3].

Theodore Billroth, a pioneer in modern prosthesis production, suggested, in 1890, that textile materials were the solution for parietal defects. Many types of materials were used over time, but each of them failed as complications or recurrences occurred, amplifying the bias linked to surgical meshes. In 1995, Francis Usher turned his attention to synthetic materials as Nylon, Orlon acrylic fibres, Dacron or Teflon, which could solve issues related to complications or recurrences, but had their own inconveniences. Afterwards, he used polymeric materials and created woven meshes initially, then knitted, which proved remarkable qualities. In 1958, he published his own surgical technique using a polypropylene mesh and 30 years later the procedure became very popular as "tension-free" mesh surgical repair, known until today as Lichtenstein procedure.

A meta-analysis of 58 randomized trials, performed in 2002 , proved the superiority of surgical meshes over other tissue repair procedures used in hernia treatment, regarding the recurrence rate $(2.7 \%$ vs. $8.2 \%$ in ventral hernias and a $50 \%$ to $75 \%$ decrease in inguinal hernias recurrences) [4].

Nowadays, over 200 types of textile meshes are available worldwide for tissue reinforcement surgeries of the abdominal wall, pelvic floor, diaphragm, or thoracic wall [5]. A correct and rational choice of the optimal textile prostheses in abdominal and pelvic surgery is of great importance in reducing, as much as possible, the risk of postoperative complications and poor clinical outcome.

\section{CLASSIFICATION OF SURGICAL MESHES}

Surgical meshes can be classified by the type, properties, and structure of the fibres that compose them. Depending on the fibre type, meshes may be: biological (acellular collagen matrix from human, bovine or porcine dermis, bovine pericardium or porcine intestinal submucosa) or synthetic, which, in turn, may be polymer (polypropylene - PP, polytetrafluoroethylene - PTFE, including the expanded form ePTFE, polyester, polyethylene terephthalate - PET, polyvinylidene fluoride - PVDF, polylactide - PLA, polyglycolic acid - PGA, polycaprolactone - PCL, polydioxanone - PDO, monocryl, hyaluronate), metallic (titanium) or composite (multiple layers of combined materials).

Regarding fibre properties, there are absorbable or non-absorbable meshes.

According to the fibre structure, implantable textiles could be monofilament or multifilament.

Another classification criterion is porosity. Consequently, meshes are micro-porous, macroporous or submicron.

Finally, based on their density (weight), meshes may be ultra-lightweight $\left(<35 \mathrm{~g} / \mathrm{m}^{2}\right)$, light-weight
(35-69 $\left.\mathrm{g} / \mathrm{m}^{2}\right)$, standard $\left(70-139 \mathrm{~g} / \mathrm{m}^{2}\right)$ or heavyweight $\left(\geq 140 \mathrm{~g} / \mathrm{m}^{2}\right)[2,6-8]$.

\section{PROSTHETIC MATERIAL INTEGRATION}

Any prosthetic material implantation is rapidly followed by a complex series of events that mark the beginning of tissue healing. This process occurs in 3 successive stages: inflammation, cellular proliferation, and tissue remodelling.

After implantation, the prosthetic material absorbs proteins, creating a coagulum that contains albumin, fibrinogen, plasminogen, complement factors, immunoglobulin. The next stage is platelet aggregation and degranulation, with release of chemotactic factors that will recruit neutrophils (thus starting the acute inflammation process), monocytes, $\mathrm{T}$ lymphocytes, fibroblasts. The primary role of neutrophils is to destroy bacteria and cellular debris. Also, cytokines are released and play a role in angiogenesis and collagen synthesis. After PMN cells destruction, components that act like mediators and sustain inflammatory process are released on the surface of the implanted material [9].

Proliferation stage (days 4 to 12 ) is characterized by granulation tissue formation. During this stage, fibroblasts recruited by the chemotactic factors proliferate. Components of the extracellular matrix are synthesized and contribute to the structural integrity of the conjunctive tissue. Stimulated by the chemokines and by the growth factors, endothelial cells proliferate, migrate, and take part in the angiogenesis process. Angiogenesis requires ATP, oxygen and nutrients and is an essential stage in the tissue healing process. Regarding the prosthetic materialtissue interaction, three histological aspects are of major importance: the extent of tissue reaction, cellular density, and fibroblast activity. The optimum quantity of fibroblasts required for an adequate healing is reached 2 weeks after contact (aggression).

Additional recruitment of fibroblasts leads to inflammation with associated fibrosis and more rapid integration of the prosthetic material. As a result, pain and paresthesia may occur. The inflammatory process may lead to adhesions and subsequent fistulas [9].

The last stage of tissue healing consists in extracellular matrix reorganization. The thin fibres of immature collagen thicken and reorganize, transforming into mature type 1 collagen. Myofibroblasts reduce in size and produce tissue shrinkage, to reduce collagen deposition. The retraction is accentuated by cross-linking of the collagen fibres. There is a constant turnover of collagen in the extracellular matrix, both at the level of the tissues undergoing healing and during the normal tissue homeostasis, which is ensured by the balance between collagen production and its degradation, under the action of collagenase, a metalloproteinase whose activation is controlled by cytokines and growth factors. This balance is the ultimate determinant of tissue integrity and resistance [9]. 
Prosthetic material integration is a progressive process. It starts with the first stage of the tissue healing process. Tissue resistance increases during the maturation and remodelling stages (may last up to 12 months). The result is a rigid tissue with $70-80 \%$ of the initial structure's elasticity [9].

Latest research on parietal defects brought valuable information regarding the structural and functional parameters of surgical meshes that may influence the immune response or may reduce fibrosis.

\section{PHYSICOCHEMICAL PROPERTIES}

The quality of the implanted material has an impact on the benefit-risk balance of the surgery [5]. Understanding of the physicochemical properties of surgical meshes is essential for the rational choice of the optimal device [10].

\section{Mechanical parameters}

Tensile strength

Tensile strength is the maximum force that can be applied to a mesh, without causing it to deteriorate or break, accidents that could lead to an unsatisfactory clinical outcome or complications such as recurrence. Thus, the material from which the mesh is constructed must withstand the maximum tension that can be generated at the level of the abdominal wall. This was measured in multiple studies, having individual variations and depending on the anatomical region (maximum $39 \mathrm{~N} / \mathrm{cm}$ at the white line, $28 \mathrm{~N} / \mathrm{cm}$ in the transverse direction, or $16 \mathrm{~N} / \mathrm{cm}$ in the groin region [11-14].

Elasticity

Elasticity is the property of a material to return to its original shape and dimension, following the deformation produced by force acting on it.

The use of meshes for the surgical treatment of incisional hernias increases the parietal elasticity, thus decreasing the recurrence rate. At tensile strength of $16 \mathrm{~N} / \mathrm{cm}$, light meshes develop elasticity of $20-35 \%$, while heavy meshes reach halved values (4-15\%). At the same time, using a mesh with improper tension can lead to a change in its elasticity, having an impact on the functional results, as well as generating complications such as pain, prolapse or recurrence, the latter being more frequent at the edges of the mesh $[15,16]$.

\section{Structural parameters}

\section{Porosity}

Porosity is the main determinant of tissue reaction to implanted material [6]. Cellular and bacterial proliferation depends to a large extent on the porosity, both in terms of pore size and their shape change, occurring through the tensioning of the mesh, having, along with the mechanical, structural or mesh size characteristics, a major influence on its integration [15]. Porosity is generally defined as the percentage of the mesh not covered by filaments. This notion defines the "textile" porosity, while the effective porosity, a term introduced by Muhl et al., is represented by the percentage of the mesh not covered by the fibrous bridges (formed by the confluence of the granulomas) and is ensured by keeping a minimum inter-filament distance. Studies showed that macroporous meshes with PTFE coating were correlated with the lowest rate of inflammatory response, while micro-porous meshes exhibited a larger inflammatory response and were more frequently associated with complications such as infection or pain [17]. Multiple classification attempts have resulted from the difficulty of establishing the ideal size of the pores, as this is influenced by the type of the composing fibres, but also by the pore geometry $[15,18$, 19]. Macro-porous meshes develop inflammatory reaction, fistulas, calcification of small magnitude compared to micro-porous ones and will have better flexibility, by avoiding the formation of fibrosis bridges. Micro-porous polypropylene meshes, are more susceptible to bridging, leading to encapsulation of the prosthetic material, resulting in a flat, rigid scar. Also, the pore geometry can have an impact on the integration of the meshes, the hexagonal pores demonstrating the best tissue impregnation, followed by the square and the rhomboid ones [20].

Density (weight)

The density of the prosthetic material depends on the weight and quantity of fibres from which it is manufactured. Heavy meshes (generally $>100 \mathrm{~g} / \mathrm{m}^{2}$ ) are made of thick polymeric fibres, are micro-porous and have high tension, while light meshes contain thinner filaments, have large pores (>1 mm) and, therefore, a small amount of material, resulting in a low-intensity foreign body reaction, with higher mesh integration and fewer complications [2]. Light meshes are also more elastic and the new generation of ultra-light composite (titanium/polypropylene) meshes offers faster post-operative recovery, sometimes in exchange for reduced tensile strength $(12 \mathrm{~N} / \mathrm{cm})$, in the case of the lightest ones in this category $[6,21]$. Although it is generally considered an advantage, the low weight can also have shortcomings, the lightweight meshes being more elastic and flexible, which can create problems in their intra-operative handling. This may be solved by adding absorbable filaments that will increase the weight and, consequently, the manoeuvrability of the prosthetic material.

\section{Composition}

Synthetic meshes

The surgical meshes are made of monofilament or multifilament yarns. Monofilament yarns provide satisfactory support, but form a rigid and slightly foldable mesh. By contrast, the meshes made of multifilament yarn (twisted or braided) are softer and can be folded more easily, but they present a higher risk of infection, leading to the erosion of the mesh in $20-30 \%$ of cases. Bacterial adhesion and proliferation occur mainly in the small spaces $(<10 \mu \mathrm{m})$ between the yarns or between the filaments that compose the yarns [22].The fibres that form the mesh are, in turn, 
made of various materials, so that the meshes can be synthetic, biological or composite, absorbable or nonabsorbable [1], the ultimate goal being to ensure the best biocompatibility, thus preventing complications such as recurrence of hernia, abdominal pain, infection or seroma formation [23]. The most commonly used non-absorbable synthetic materials are polypropylene, polyester and expanded polytetrafluoroethylene (ePTFE).

Polypropylene is a widely used polymer due to its special strength, comparable to that of steel. Available polypropylene meshes, single- or multi-filament, are either coated - for intra-peritoneal use, or uncoated - for extra-peritoneal mounting (figures 1 and 2). Both forms can cause complications, mainly due to the weight of the mesh. These consist of an intense inflammatory response, with the formation of thick scars and mesh shrinkage (up to $30-50 \%$ ), which may eventually cause the recurrence of the hernia. Lately, in an attempt to prevent these shortcomings, ultra-light meshes have been created, which generate a less rigid abdominal wall-mesh complex, with greater mobility and significantly reduced pain [1]. In general, polypropylene is considered to be an inert material, stable and sufficiently resistant over time, offering a suitable service life in vivo [24].

Polyester meshes are multifilament meshes, made of PET, which can generate resistant fibres [1,2]. These meshes have advantages such as minimal adhesion, reduced stiffness and contraction or better integration and are available in multiple configurations for repair of inguinal, ventral or hiatal parietal defects, mainly by classical approach. In order to be intra-peritoneal mounted, these meshes are coated with collagen, which prevents adhesion to the intestines and complications occurrence. The multifilament nature of the fibres that compose them results in an increased susceptibility of these meshes to postoperative infections and fistulas. During infections, mesh degradation is accelerated, which may lead to recurrence of hernia. Regarding the inflammatory response generated, the adverse reactions or the complications occurrence rate, these are comparable to those of polypropylene meshes [1, 22].

ePTFE is used in the manufacture of micro-porous meshes, having disadvantages like: poor tissue integration, with encapsulation and possible parietal defect recurrence, or increased risk of infection - as small pores allow bacterial passage, but not that of macrophages, so that an infected encapsulated mesh will have to be explanted [2, 22]. Compared to PP and PET, ePTFE causes minimal inflammatory reaction and formation of scar tissue with comparable densities, which makes it suitable for intra-peritoneal use, allowing it to be placed in contact with viscera. However, it has low resistance, so it is important to be well fixed [1, 2].

\section{Composite meshes}

To prevent visceral adhesion, synthetic surgical meshes can be coated with absorbable or nonabsorbable materials. Those are attached to the surface that will come in contact with the viscera, forming a protective barrier, which will diminish the inflammatory response. The substances used to create barrier layers can be: ePTFE, polyurethane, oxidized regenerated cellulose, omega-3 fatty acids, collagen or Beta-glucans.

Another method to reduce the tissue reaction is to use partially absorbable meshes, which reduce their density by up to $50 \%$ in up to 9 months after implantation. Reducing the amount of biomaterial leads to the reduction of inflammation and results in enlargement of the pores, facilitating the integration of the prosthesis [1, 24].

Also, to prevent complications, dual meshes can be used, which will benefit from the advantages of both materials. Those made of polyester and PTFE, having different chemical properties and porosity, will allow a good integration at the level of the abdominal wall, preventing visceral adhesion. Recently, dual meshes of polyester or polypropylene with temporary barriers were created, as, according to studies, visceral adhesions occur in the first postoperative week [1].

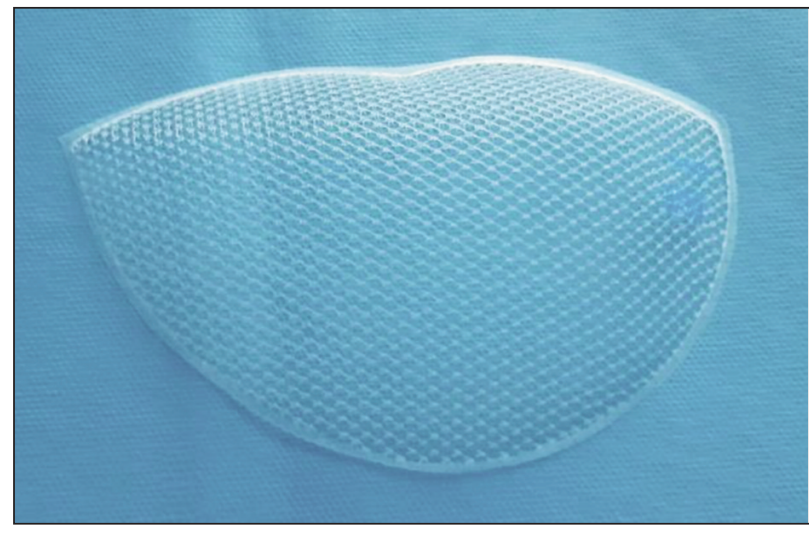

Fig. 1. Polypropylene mesh used in inguinal hernia repair. Courtesy of "Carol Davila" Central Military Emergency University Hospital, Department of General Surgery

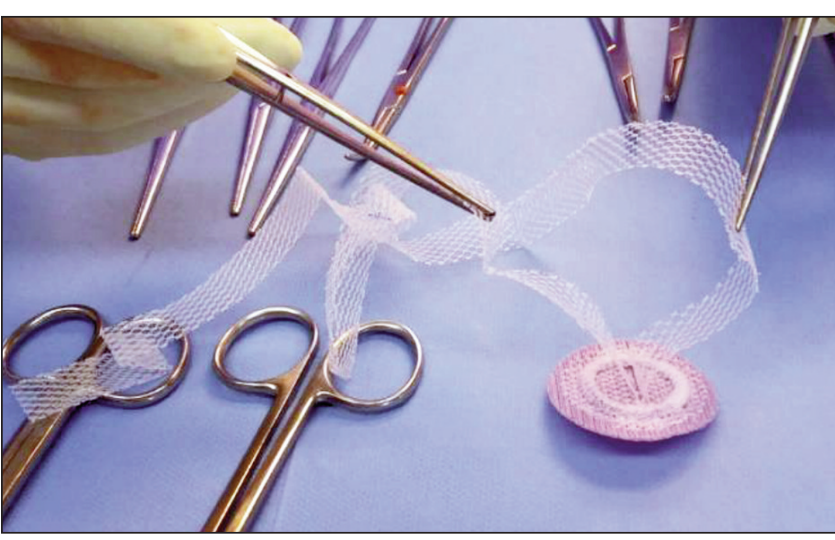

Fig. 2. Polypropylene mesh used in umbilical hernia repair. Courtesy of "Carol Davila" Central Military Emergency University Hospital, Department of General Surgery 


\section{Biological meshes}

Hernia repair may be a major challenge in case of complex parietal defects, which require open surgery and which involve contamination or infection. In these circumstances, the use of a biological prosthesis may be considered, both at the time of closure per primam and at revision, in order to avoid further interventions in advanced stages, with high morbidity. Biological meshes have been successfully used in over $75 \%$ of the ventral defects repair, under contamination conditions, while, under aseptic conditions, the rates reach even $90 \%$ [2].

The biological materials are derived from human or porcine dermis, fetal tissue, bovine pericardium or porcine intestinal submucosa, tissues that are decellularized and will only have a supporting role, providing the collagenous matrix on which the future connective tissue will be attached. Removal of cellular components offers the advantage of eliminating the inflammatory response and immune-mediated rejection, while retaining structural and functional proteins, glycosaminoglycans, glycoproteins or growth factors, which will predominantly modulate the tissue healing response, disfavouring scar tissue formation. Biologic materials can also induce angiogenesis, being successfully used in contaminated interventions and having shown some degree of resistance to adhesion formation [4]

Although extremely promising for repair surgery, biological prostheses, however, have shortcomings such as low resistance of the newly formed connective tissue (70-80\%), with high long-term recurrence rates, or the possibility, at least theoretically, of transmitting other diseases. All of these come at a relatively high cost, thus limiting their use [4].

\section{Mesh manufacturing}

Meshes can be woven or knitted. By bending the yarns, the latter form much more flexible and elastic structures than the woven ones, whose yarns have a unilateral orientation. Knitted meshes adapt more easily to the anatomical changes generated by the movement of the body, can generate higher tensile strengths and have a good porosity, key features of any implantable material. Also, the knitting process generates a stable structure, which does not loosen or peel off when cut. Implantable knitted textiles, monofilament or multifilament, composed of various materials are successfully commercialized and used worldwide [4].

\section{INDICATIONS}

Surgeons should choose a mesh adequate to the situation. Prosthetic meshes are categorized according to their purpose: i) abdominal or thoracic wall reconstruction; ii) visceral defects repair; iii) pelvic floor stabilization (rectal or vaginal prolapse); iv) tissue replacement (skin graft, endovascular graft for by-pass).
A lightweight mesh, with high porosity and minimal contact surface, ideally monofilament, is usually preferred. Therefore, polypropylene or polyester meshes are commonly used due to their viability and low infection rate. The ideal mesh should be monofilament, with high porosity, anisotropic properties and biocompatible with the host [10].

In general surgery, meshes are electively used to repair abdominal wall defects. Placing a mesh can be done by classic surgery (Rives-Stoppa, Lichtenstein) or laparoscopic (TAPP, TEP, IPOM).

Indications for surgical mesh are: recurrent hernias, an abdominal defect larger than $4 \mathrm{~cm}$, incisional hernias, multiple hernias, defects in proximity of bones, older patients, and presence of ascites, obesity, conjunctive tissue abnormalities, important weight loss or the need for a fast recovery. One special indication is the incisional hernia after minimally invasive surgery like laparoscopic techniques or robotic surgery techniques. Robotics is a minimally invasive technique, similar to laparoscopic surgery, in which working tools are inserted through small incisions of $5-15 \mathrm{~mm}$ in the peritoneal cavity through which cannula are introduced to work [25].

For plastic and reconstructive surgery, biomaterials are used in order to support and repair soft tissue. These biomaterial prosthetics are indicated for breast, hand, or face reconstruction [26]. In gynecology, meshes are used to strengthen the pelvic floor in order to treat prolapse or urinary incontinence. Transobturatory tape procedure is efficient in low morbidity cases and it may become the new gold standard for treating this affection in women [27]. However, there are some complications associated with this procedure such as: rupture or contraction of the vaginal mesh, dyspareunia, dysuria, recurrent urinary tract infections, haemorrhage, and uterine prolapse recurrence. In case of pelvic prolapse, polypropylene and polyester meshes are the most susceptible to erosion [28].

\section{COMPLICATIONS}

The complications are minimal if the selected material is suitable for the surgical situation and is combined with a meticulous operating technique. Postoperative complications include chronic pain, infection, ulceration of the wound, adhesion formation, intestinal obstruction, recurrence of the parietal defect, rejection of the prosthesis and mesh granuloma or "meshoma".

\section{CONCLUSIONS}

The right choice of a suitable mesh for the surgical context is of vital importance. In the case of abdominal wall surgery, regardless of the surgical technique, it has to take into consideration the selection of a mesh with the right mechanical properties (tensile strength, elasticity, weight, pore size, biocompatibility, etc.) for the physiological characteristics of the 
patient (such as age, defect size, obesity, underlying disease process, etc.). Compatibility between these two factors is important because it can lead to a good postoperative outcome or it can be the source of complex and recurrent complications. Acquiring knowledge about these materials by the surgeon is necessary for adapting it to the situation. Therefore, in most of the cases, a monofilament light-weighted mesh with large pores is useful, whereas if the mesh is to be placed in contact with the viscera, a composite mesh with an absorbable surface should be chosen; in cases with infection, an absorbable mesh is recommended. Despite the variety of materials available for surgical meshes, surgical skill still has a high role in preventing hernia recurrence and other types of complications.

\section{REFERENCES}

[1] Elango, S., Perumalsamy, S., Ramachandran, K., \& Vadodaria, K., Mesh materials and hernia repair, In: BioMedicine, 2017, 7, 3, 16, https://doi.org/10.1051/bmdcn/2017070316

[2] Yilmaz, B., Ilker, A., The search for ideal hernia repair; mesh materials and types, In: International Journal of Surgery, 2012, 10, 6, 317-321, https://doi.org/10.1016/j.ijsu.2012.05.002

[3] Online Etymology Dictionary, Available at: https://www.etymonline.com [Accessed on June 2020]

[4] Baylón, K., Rodríguez-Camarillo, P., Elías-Zúñiga, A., Díaz-Elizondo, J.A., Gilkerson, R., Lozano, K., Past, Present and Future of Surgical Meshes: A Review, In: Membranes (Basel), 2017, 7, 3, 47, https://doi.org/10.3390/ membranes 7030047

[5] Klinge, U., Park, J.-K., Klosterhalfen, B., The Ideal Mesh?, In: Pathobiology, 2013, 80, 169-175, https://doi.org/ $10.1159 / 000348446$

[6] Brown, C.N., Finchm, J.G., Which mesh for hernia repair?, In: Ann. R. Coll. Surg. Engl., 2010, 92, 272-278, https://doi.org/10.1308/003588410X12664192076296

[7] Amid, P.K., Classification of biomaterials and their related complications in abdominal wall hernia surgery, In: Hernia, 1997, 1, 15-21, https://doi.org/10.1007/BF02426382

[8] Coda, A., Lamberti, R., Martorana, S., Classification of prosthetics used in hernia repair based on weight and biomaterial, In: Hernia, 2012, 16, 9-20, https://doi.org/10.1007/s10029-011-0868-z

[9] Schwartz, S.I., Brunicardi, F.C., eds. Schwartz's Principles Of Surgery, New York: McGraw-Hill Medical, 2011, 1, $171-176$

[10] Zhu, L.M., Schuster, P., Klinge, U., Mesh implants: An overview of crucial mesh parameters, In: World J. Gastrointest. Surg., 2015, 7, 10, 226-236, https://doi.org/10.4240/wjgs.v7.i10.226

[11] Hollinsky, C., Sandberg, S., Measurement of the tensile strength of the ventral abdominal wall in comparison with scar tissue, In: Clin. Biomech. (Bristol, Avon), 2007, 22, 88-92

[12] Williams, J.F., Kirkpatrick, J., Syme, G.A., Force measurement in the abdominal wall, In: Biomed. Eng., 1975, 10, 181-183

[13] Deeken, C.R., Abdo, M.S., Frisella, M.M., Matthews, B.D., Physicomechanical evaluation of polypropylene, polyester, and polytetrafluoroethylene meshes for inguinal hernia repair, In: J. Am. Coll. Surg., 2011, 212, 68-79

[14] Klinge, U., Klosterhalfen, B., Conze, J., Limberg, W., Obolenski, B., Ottinger, A.P., Schumpelick, V., Modified mesh for hernia repair that is adapted to the physiology of the abdominal wall, In: Eur. J. Surg., 1998, 164, 12, 951-960

[15] Zhu, L.-M., Schuster, P., Klinge, U., Mesh implants: An overview of crucial mesh parameters, In: World J. Gastrointest. Surg., 2015, 7, 10, 226-236, https://doi.org/10.4240/wjgs.v7.i10.226

[16] Junge, K., Klinge, U., Prescher, A., Giboni, P., Niewiera, M., Schumpelick, V., Elasticity of the anterior abdominal wall and impact for reparation of incisional hernias using mesh implants, In: Hernia, 2001, 5, 3, 113-118, https://doi.org/10.1007/s100290100019

[17] Klinge, U., Klosterhalfen, B., Modified classification of surgical meshes for hernia repair based on the analyses of 1,000 explanted meshes, In: Hernia: the journal of hernias and abdominal wall surgery, 2012, 16, 3, 251-258, https://doi.org/10.1007/s10029-012-0913-6

[18] Earle, D.B., Mark, L.A., Prosthetic Material in Inguinal Hernia Repair: How Do I Choose?, In: Surg. Clin. North Am., 2008, 88, 179-201, https://doi.org/10.1016/j.suc.2007.11.002

[19] Mühl, T., Binnebösel, M., Klinge, U., Goedderz, T., New objective measurement to characterize the porosity of textile implants, In: Journal of Biomedical Materials Research, Part B. Applied Biomaterials, 2008, 84B, 1

[20] Lake, S.P., Ray, S., Zihni, A.M., Thompson, D.M., Gluckstein, J., Deeken, C.R., Pore size and pore shape - but not mesh density - alter the mechanical strength of tissue ingrowth and host tissue response to synthetic mesh materials in a porcine model of ventral hernia repair, In: J. Mech. Behav. Biomed. Mater., 2015, 42, 186-197, https://doi.org/10.1016/j.jmbbm.2014.11.011

[21] Koch Frisén, A., Bringman, S., Myrelid, P., Smeds, S., Kald, A., Randomized clinical trial of groin hernia repair with titanium-coated lightweight mesh compared with standard polypropylene mesh, In: British Journal of Surgery, 2008, 95, 10, 1226-1231, https://doi.org/10.1002/bjs.6325

[22] Sanbhal, N., Miao, L., Xu, R., Khatri, A., Wang, L., Physical structure and mechanical properties of knitted hernia mesh materials: A review, In: Journal of Industrial Textiles, 2018, 48, 1, 333-360, https://doi.org/10.1177/ 1528083717690613 
[23] Rosch, R., Junge, K., Schachtrupp, A., Klinge, U., Klosterhalfen, B., Schumpelick, V., Mesh Implants in Hernia Repair, In: Eur. Surg. Res., 2003, 35, 161-166, https://doi.org/10.1159/000070045

[24] Peniston, S., Modulated Properties of Fully Absorbable Bicomponent Meshes, In: All Dissertations, 2010, 647, Available at: https://tigerprints.clemson.edu/all_dissertations/647 [Accessed on June 2020]

[25] Săvulescu, F., Duţu, C., Cirlan, C., Minimally invasive surgical techniques - robotic surgery, In: Romanian Journal of Military Medicine, 2015, CXVIII, 3

[26] Yu, D., Patel, A.T., Rossi, K., Topham, N.S., Chang, E.I., Comparison of Phasix, polypropylene, and primary closure of the abdominal donor site after bilateral free flap breast reconstruction: Long $\square$ term evaluation of abdominal hernia and bulge formation, 2019, Available at: https://onlinelibrary.wiley.com/doi/abs/10.1002/micr.30541 [Accessed on June 2020]

[27] Magon, N., Chopra, S.V., Transobturator Tape in Treatment of Stress Urinary Incontinence: It is Time for a New Gold Standard, In: North American journal of medical sciences, 2012, 4, 5, 226-230, https://doi.org/10.4103/19472714.95905

[28] Ellington, D., Richter, H., Indications, Contraindications, and Complications of Mesh in Surgical Treatment of Pelvic Organ Prolapse, In: Clinical Obstetrics and Gynecology, 2013, 56, 2, 276-288, https://doi.org/10.1097/ grf.0b013e318282f2e8

\section{Authors: \\ ALEXANDRU-FLORIN SĂVULESCU ${ }^{1,2}$, CRISTIAN CÎRLAN ${ }^{1,3}$, ANCA A. SIMIONESCU ${ }^{1}$, IULIA-ANDREEA BUDRUGEAC ${ }^{1}$, MĂDĂLINA IORDACHE-PETRESCU ${ }^{1}$, MIHAI IORDACHE ${ }^{1}$, ALEXANDRA-BIANCA IONESCU ${ }^{1}$, DRAGOȘ STANCIU ${ }^{1}$, EMMA-ILINCA SBÂRNEA ${ }^{1}$, OANA CORINA CĂLINA ${ }^{1}$}

${ }^{1}$ Carol Davila Central Military Emergency University Hospital, Bucharest, Romania

${ }^{2}$ Titu Maiorescu University of Medicine and Pharmacy, Bucharest, Romania

${ }^{3}$ Carol Davila University of Medicine and Pharmacy, Bucharest, Romania

Corresponding author:

ALEXANDRU-FLORIN SĂVULESCU MD, PhD

e-mail: savfl@yahoo.com 